ÇOMÜ Uluslararası Sosyal Bilimler Dergisi 2(4), 53-68, 2017

COMU International Journal of Social Sciences 2(4), 53-68, 2017

\title{
Suriyeli Mülteci Kadınların Sosyo-Kültürel Değişime Uyum Çabaları: Yozgat Örneği
}

Hülya ÇAKIR*

Öz

Suriyeli mültecilerden özellikle barınma merkezleri dışında kalanlar, kentlerde ekonomik, sosyal ve kültürel sorunlar yaşamakta, yaşanan bu sorunlara bağlı olarak bir uyum sorunu ortaya çıkmaktadır. Sosyo-kültürel değişime uyum sorununun Yozgat özelinde ele alındığı bu çalışmada amaç, kent merkezinde yaşayan Suriyeli mültecilerin yaşadıkları sorunları tespit etmek ve bu konularda çözümler geliştirmektir. Çalışmada nitel yöntem tercih edilmiş ve mülakat tekniği kullanılmıştır. Bu nedenle çalışma kapsamında, 15 kadınla, derinlemesine görüşmeler gerçekleştirilmiştir. Araştırmanın verileri Suriyeli mültecilerle yapılan derinlemesine görüşmelerden elde edilmiştir. Elde edilen sonuçlar, "yerleşim yeri olarak Yozgat, iletişim aracı olarak dil, kültürel farklılıklar, temel hizmetlere erişim ve "kadın" olmaları dolayısıyla yaşadıkları olumsuzluklar konu başlıkları altında değerlendirilmiştir.

Anahtar Kelimeler: Suriyeli Mülteciler, Uyum, Sosyo-Kültürel Değişme.

\section{Socio-Cultural Change Adaptations of Syrian Refugee Women: The Case of Yozgat}

\begin{abstract}
Syrian refugees, especially those who are not residents of shelters, experience economic, social and cultural problems in cities and a problem of integration arises due to these living conditions. The aim of this study is to identify the problems of the Syrian refugees living in the city center and to develop solutions for these issues in Yozgat's problem of socio-cultural change adaptation problem. Qualitative method was preferred in the study and interview technique was used. For this reason, in-depth interviews were conducted with 15 women. The data from the study were obtained from in-depth interviews with Syrian refugees. The results obtained are as follows: "Yozgat as a settlement is evaluated under the headings of language, cultural differences, access to basic services and the difficulties that women experience due to their gender.
\end{abstract}

Keywords: Syrian Refugees, Integration, Socio-Cultural Change.

* Yrd. Doç. Dr., Bozok Üniversitesi Sosyoloji Bölümü, hulya.cakir@bozok.edu.tr 


\section{GíRiş}

Kuzey Afrika ve Ortadoğu'yu içine alan geniş bir coğrafyada, iktidarları boyunca dünyanın birçok demokratik ülkesinde neredeyse iki kuşak devlet adamlarının siyaset sahnesine gelip gittiği kadar uzun süre görevde kalan ve dokunulmasa belki bir kuşak daha eskitecek olan diktatörleri birkaç ay süren kanlı bir mücadele sonunda deviren halk hareketine kısaca "Arap Baharı" denilmektedir (Kibaroğlu, 2011: 26). Arap Baharı bölge ülkeleri arasında hiç kuşkusuz Türkiye'yi de etkilemektedir. Kimi gözlemcilere göre bu etki genelde olumsuzdur. Türkiye'nin Irak, İran ve Suriye'yle olan ilişkilerinde uygulamaya çaIıştığı 'komşularla sıfir sorun' politikası uygulanamaz hale gelmiştir. Suriye ile kurulan ilişkiler, Ankara'nın Esad karşısındaki muhalif unsurları desteklemesi ve Esad'ın Türkiye'nin uyarılarını bir türlü ciddiye alıp ülkesinde gerekli liberal demokratik reformları yapmaması nedeniyle sona ermiştir (Oğuzlu, 2011: 15). Mısır ve Libya'da sürecin büyük oranda Türkiye'nin beklentileri doğrultusunda gelişmesi sebebiyle dış politika alanında öncelikli bir konu olmaktan çıkarken, Suriye'de 2011 itibariyle Beşar Esad'ın gerek Türkiye'nin, gerek içinde uzun yıllar çok etkin rol oynadığı Arap Birliği'nin uyarılarına olumlu yaklaşma niyetinin ufukta olmadığı gözlemlenmektedir (Kibaroğlu, 2011: 33).

Nisan 2011'den bu yana Suriye'de çıkan rejim karşıtı gösterilerin kanlı bir biçimde bastırılmasının yarattı̆̆ karmaşa ve ardından yaşanan iç savaş nedeni ile ülkelerinden kaçan Suriyelileri, 1980'lerden bu yana Orta Doğu, Asya, Doğu Avrupa ve Afrika'nın bir bölümü gibi çeşitli göç rotalarından istikrarlı göç akını yaşayan (Biehl, 2008: 6-7), uluslararası hukukun ve vicdanın gereğini yerine getirerek Türkiye "açık kapı politikası" çerçevesinde "geçici koruma" sağlayarak kabul etmiştir. Bu durum başta İnsan Hakları Evrensel Beyannamesi ve 1951 Cenevre Anlaşması olmak üzere uluslararası hukuk ilkeleriyle uyumlu bir politikadır (HUGO, 2014: 11).

Türkiye, ilk göç dalgalarının yaşandığı sırada, savaşın uzun sürmeyeceği ve göç edenlerin tekrar ülkelerine döneceği beklentisi ile açık kapı politikası izlemiş ve göçün yönetimine dair kapsamlı önlemler almamıştır (Mozaik Kadın ve Aile Derneği, 2015:4). Akabinde Suriye'de kitlesel kıyımların yaşandığı çok daha dramatik bir tablo ortaya çıkmış ve başka ülkelere sığınan Suriyelilerin geri dönüş ihtimalleri ise oldukça azalmıştr. Yaşanan politik süreçte, mevcut tüm veriler Suriye'de yaşanan krizin uzun yıllara yayılacağı öngörüsünü desteklemiştir (İnsan Hakları ve Mazlumlar İçin Dayanışma Derneği, 2014: 11). Mülteci krizi, Türk devletini iltica ve uluslararası koruma konusundaki yasal çerçevesini tekrar gözden geçirmeye ve mevcut reform çabalarını hızlandırmaya itmiştir (İçduygu, 2015:9). Önce, uluslararası hukukta herhangi bir karşılı̆̆ bulunmayan "misafir" statüsü verilen mültecilere, 2012 yılı Nisan ayında yayınlanan genelge ile "geçici koruma" statüsü verilmiş, aynı yıl Ekim ayında da, sağladığı bu geçici korumayı genişletmiştir.

Birleşmiş Milletler (BM) Mülteciler Yüksek Komiserliği'nin açıkladığı son mülteci bilgilerine göre, Suriye'deki savaş dolayısıyla 7 milyon 600 bin Suriyeli evlerini terk edip ülke içinde başka bir bölgeye kaçmak zorunda kalmıştır. Suriye vatandaşı iç savaş nedeniyle ülkelerini terk ederek Türkiye, Lübnan, Ürdün, Irak gibi komşu ülkelere ve hatta Avrupa'ya sığınmış bulunmaktadır. Suriye'nin güneydeki komşusu Lübnan'da 1 milyon 78 bin, Ürdün'de ise 628 binden fazla mülteci bulunaktadır. Bu ülkeler içerisinde en fazla mülteci barındıran ülke Türkiye'dir. 
2011 Baharı'nda Suriyelilerin Türkiye sınırına gelmeye başladığı ilk günden itibaren bütün girişlere izin verilmiştir. Normal zamanlardaki gibi pasaportlarla girenlerin yanı sıra, hiçbir belgesi olmadan gelenler de Türkiye tarafindan kurulan geçici mülteci kamplarına kabul edilmiştir. Ancak 2012 yazına doğru mülteci sayısının artmaya devam etmesi ve özellikle de Halep ve çevresinde yaşanan çatışmaların yoğunlaşması sonucu kampların kapasitesi zorlanmaya başlamış, 2012'nin ikinci yarısında hükümet, Türkiye'ye girişleri sınırlamak için kimi önlemlere başvurmak durumunda kalmıştır. Bu durum, sınırın Suriye tarafinda Türkiye'ye kabul edilmeyi bekleyen kalabalık gruplar halindeki Suriyeliler için 20'den fazla geçici kamp kurulmasıyla sonuçlanmıştır. Bu geçici kamplardan bazıları Atme, Bab el-Hava ve Bab es-Selame vb. kısa zaman sonra sınır boyunca uzanan yarı-kalıcı merkezlere dönüşmüştür. Bu arada Suriye'nin kuzeyindeki şiddetten kaçan Suriyeliler de gayri resmî yolları kullanarak Türkiye'ye girmeye başlamış ve Türkiye'deki “kamplarda kalmayan mülteci nüfusu" saflarına katılmıştır (Dinçer vd., 2013:11-31).

Araştırma verileri kamplarda kalmayan, Birleşmiş Milletler Mülteciler Yüksek Komiserliği (UNHCR) aracılığıyla Yozgat’a gönderilen Suriyeli mültecilerle yapılan görüşmelere, onların mikro-sosyolojik düzeyde yaşadıkları deneyimlerine dayanmaktadır. Araştırmada yöntem olarak nitel yöntem benimsenmiş ve mülakat tekniği kullanılmıştır. Bu bağlamda literatür taraması ve Suriyeli mültecilerden 15 kişi ile gerek doğrudan ve gerekse tercüman aracılığıyla 2017 yılının Şubat, Mart ve Ağustos aylarında yarı yapılandırılmış görüşme formu kullanılarak derinlemesine görüşmeler ile veri toplanmış ve elde edilen bulgular analiz edilmiştir.

Bu çalışmada kültürel farklılıkların hangi konularda belirginleştiği, süreç içerisinde bir benzeşme ortaya çıııp çıkmadığı; mülteci kadınların kültürel hayatta herhangi bir problemle karşılaşıp karşılaşmadığı konuları üzerinde durulmaktadır. Suriyeli mültecilerin yeni topluma ve bu toplumunun kültürüne, yaşam biçimine uyum sağlaması gerekmektedir. İki farklı toplumun çatışmadan, uyum içerisinde yaşaması her iki topluluk için de büyük önem taşımaktadır.

\section{KAVRAMSAL ÇERÇEVE: SOSYO-KÜLTÜREL YAPI VE GÖÇ 1.1. Sosyo-Kültürel Yapı}

Sosyo-kültürel yapı faktörleri, insanları en çok etkileyen faktördür. Bu faktörler bireyin içinde yaşadığı toplumun sosyo-kültürel özelliklerini oluşturmaktadır. Her birey belirli bir kültürel yapı içinde yaşamakta ve bu yapıyla sürekli etkileşim halinde bulunmaktadır. Bireyin idealleri ve ilgileri de bu kültürel ortamda şekillenmektedir (Tutar, 2016: 52).

Sosyo-kültürel değişme sosyal kurumlarda, kurumlararası ilişkilerde ve kültürü oluşturan, maddi ve manevi kültür, ünite ve komplekslerindeki değişme olarak ifade edilebilmektedir (Akkayan,1979: 15). Sosyo-kültürel yapı, sosyal ve kültürel unsurların basit bir toplamı değildir. Bu yapıyı oluşturan farklı nitelikler ve özellikler vardır. Sosyo-kültürel yapı, makro ve mikro bütün etkileşim düzlemlerinde, davranışsal ve bilişsel boyutların birbirinden ayrılmazlığı düşüncesini ifade etmektedir (Dikeçligil,1997:4).

Sanayileşme, nüfus artş̧ı ve yabancı ülkelerin tahriki gibi sebeplerle günümüz toplumlarında sosyo-kültürel bütünleşme en önemli problemlerden biri haline gelmiştir. İntegrasyon, latince Integre (eksiği tamamlama, ilave) kökünden gelmektedir. İntegrasyon, dağılan bir bütünün parçalarının yeniden birleştirilmesi ve bir merkezde toplanmasını 
ifade etmektedir. Bütünleşme kelimesi, çoğu zaman "dayanışma, birlik, denge ve düzen" kelimeleriyle aynı anlamda kullanılmıştır. Bütünleşme terimi çoğu zaman sosyalleşme ve kültürleşme gibi sosyal süreçlerin söz konusu olduğunu göstermektedir. Örneğin köyden şehire göç eden köylü veya bir ülkeden diğerine göç eden mülteci, çevrenin davranış modellerini benimsediği ve önce kendisine yabancı olan kimselerle sosyal ilişkilerini geliştirdiği zaman sosyo-kültürel bütünleşme sürecinden geçmiş olmaktadır. Sosyal değerler toplumsal bütünleşmenin özünü teşkil etmekte ve toplumun fertlerini, sınıflarını ve kurumlarını birleştirmekte rol oynamaktadırlar. Bu değerler sarsıntıya uğradığı zaman toplumda çözülme hali baş göstermektedir (Arslanoğlu, 1996: 39).

Ülkemizde de, şu ana kadar sayısı milyonları aşar durumda mültecinin bulunduğu ve birçoğunun sınır illere ve yakın kentlere göç ettiği bilinmektedir. Suriye'den mülteci akını devam etmekte ve mülteciler, göç ettikleri kentlerde uyum sorunu yaşamaktadırlar.

\subsection{Göç ve Mültecilik}

Göç, kişilerin ekonomik, dini, siyasi ve sosyal sebeplerden dolayı yerleşmek amacıyla bir yerden başka bir yere gitmeleri hareketine denilmektedir. Bu hareket, ülke içinde olursa 'iç göç', ülkeler arasında olursa 'dış göç' veya 'uluslararası göç' olarak adlandırımaktadır. Göç, bireylerin ya da grupların bir yerden başka bir yere gitmeleri ve gidilen yerde yaşamlarını belli bir süre sürdürmeleri olarak ifade edilebilir (Çakır, 2011:215).

Mültecilerin Statüsüne İlişkin 1951 Sözleşmesi' ne göre mülteci "ırkı, dini, milliyeti, belli bir sosyal gruba mensubiyeti veya siyasi düşünceleri nedeniyle zulüm göreceği konusunda haklı bir korku taşıyan ve bu yüzden ülkesinden ayrılan ve korkusu nedeniyle geri dönemeyen veya dönmek istemeyen kişi" dir (http://www.unhcr.org).

Cenevre Sözleşmesi'ne göre, bir kişinin mülteci sayılabilmesi için beş ölçüte bakılmaktadır: ırk, din, tabiiyet ve siyasi düşünceleriyle belli bir toplumsal gruba mensup olma; zulme uğrayacağından haklı sebeplerle korkma; vatandaşı olduğu ülkenin dışında bulunma; ülkesinin korumasından yararlanamama veya korku nedeniyle yararlanmak istememe; vatansız olma ve yaşadığı ikamet ülkesine dönememe veya söz konusu korku nedeniyle dönmek istememedir. Ancak bu niteliklere sahip olmanın dışında, coğrafi bakımdan da uyumlu olması gerekmektedir. Bu sözleşme bağlamında Türkiye, ülkelere bırakılan bazı şerh haklarından 'coğrafi sınırlama hakkını' kullanarak sadece Avrupa'dan gelen insanları mülteci olarak kabul ettiğini beyan etmiştir (Buz, 2008:120).

Ülkemizdeki Suriyelilere ne denilmesi gerektiği konusunda da farklı görüşler ortaya konulmaktadır. Aslında yaşanılan karmaşa Türkiye'deki hukuk sisteminden kaynaklanmaktadır. Uluslararası Af Örgütü tarafindan en son yayınlanan "Hayatta Kalma Mücadelesi”nde Türkiye'deki Suriye'den Gelen Mülteciler başlıklı rapora şu not düşülmüştür: "Uluslararası Af Örgütü, tüm Suriyelilerin prima facie (varışta mülteci) olarak uluslararası hukuk uyarınca mülteci korumasına hakları olduğu görüşündedir ve dolayısıyla Türkiye'de bulunan Suriyelileri, Türkiye hukukundaki statülerine bakmaksızın, mülteci olarak adlandırmaktadır." Sonuç olarak, haberlerde Türkiye'ye Avrupa dışından gelenlere geliş nedenlerine bakılarak mülteci denilebilir (http://bianet.org/bianet/ bianet/167434-multeci-gocmen-siginmaci-arasindaki-farklar)

Tüm mültecilerin yaşadığı sorunları kadın mülteciler de yaşar. "Hassas grup" olarak tanımlanan kadın mülteciler de diğer mülteciler gibi, silahlı çatışma ve şiddetin türlerine 
karşı güvenliğe; açıklanamayan ve sebepsiz yere uzatılan gözaltına alınma tehlikesine karşı korunmaya; kendilerine yeterli sosyal, ekonomik ve yasal haklar tanıyan hukuki bir statüye; beslenme, barınma, giyim, öz bakım ve sağlık gibi temel ihtiyaçların karşılanmasına gereksinim duyar. Ancak mülteci kadınlara tanınan haklar, 1951 tarihli "Cenevre Sözleşmesi" ve "1967 Protokolü"nde düzenlenenlerle sınırlı değildir. "Insan Hakları Evrensel Bildirgesi", "Cenevre Sözleşmeleri" ve iki ek protokolü, "Kişisel ve Siyasal Haklar Uluslararası Sözleşmesi", "Ekonomik, Sosyal ve Kültürel Haklar Uluslararası Sözleşmesi”, "Kadınlara Karşı Her Türlü Ayrımcılığın Ortadan kaldırılmasına Dair Sözleşme (CEDAW)", "Kadınlara Karşı Şiddetin Tasfiye Edilmesine Dair Bildirge (DEVAW)", "Olağanüstü ve Silahlı Çatışma Hallerinde Kadınların ve Çocukların Korunmasına Dair Bildiri", "Evli Kadınların Uyrukluğu Sözleşmesi" ve "Çocuk Haklarına Dair Sözleşme" de mülteci kadınların haklarının yer aldığı uluslararası metinlerdir. Bu belgeler, tüm devletler tarafindan imzalanmamış olsa da, mülteci kadınlara ilişkin koruma ve yardım açısından uluslararası insan hakları standartlarına dair bir çerçeve sağlamaktadır (İnsan Hakları ve Mazlumlar İçin Dayanışma Derneği, 2014: 22).

Suriyeli mültecilerin \% 13-14'ü 15 ildeki 22 kampta (barınma merkezi) yaşamakta, ama asıl büyük kitle yani en az 1,4 milyonu Türkiye'nin 81 ilinden 9'u hariç hemen her tarafina yayılmış olarak kamp dışında yaşamaktadır. Kamplar dışında en yüksek sayıda Suriyelinin yaşadığı şehir 387 bin civarındaki mülteci ile Şanlıurfa, ardından da 330 bin kişi ile İstanbul'dur. Bunları 220 bin kişi ile Gaziantep, 190 bin kişi ile Hatay takip etmektedir. Kilis 49 bin, Mardin 70 bin, Adana 50 bin ve Kahramanmaraş 44 bin kişi ile kamp dışında yaşayan Suriyelilere ev sahipliği yapmaktadır. Türkiye'nin 11 ilinde ise 15 ile 50 bin arası Suriyeli kamplar dışında yaşamaktadır (HUGO, 2014: 11).

İçişleri Bakanlığı'nın 2014 yılı verilerine göre; araştırma bölgemiz olan Yozgat'ta 50 Suriyeli mülteci yaşamakta iken Mart 2017 itibariyle kayıtlı olanların sayısı 3 bin 352'ye yükselmiştir. Bu sayı nüfusu 421.041 olan Yozgat'ın kendi nüfusu ile karşılaştırıldığında \%0.80 sonucunu ortaya çıkarmaktadır (Yozgat Valiliği III Göç İdaresi Müdürlüğü). Bu durum sürekli göç veren Yozgat'ın nüfusunun mültecilerle artmakta olduğunu göstermesi açısından oldukça önemlidir. Ayrıca göçün, sadece nüfus yapısını etkilememesi, göç eden insanların beraberlerinde kendi kültürlerini de götürmeleri dolayısıyla sosyo-kültürel yapıyı da etkilemesi (Demir, 2008:3) bu çalışmayı hem önemli hem de gerekli kılmaktadır.

\section{YOZGAT'A GÖÇLERIN EKONOMIK VE SOSYO-KÜLTÜREL ETKILLRI 2.1. Ekonomik Etkiler}

Adrese Dayalı Nüfus Kayıt Sistemi (ADNKS)'ne göre 2014 yılında 432 bin 560 olan Yozgat'ın nüfusu 2015 yılı sonu itibariyle 13 bin 120 eksilerek 419 bin 440'a düşmüştür. 2015 yılında en çok göç veren il olan Yozgat'ta nüfus artı̧ oranı binde eksi 30 olarak gerçekleşmiştir. Adrese dayalı nüfus kayıt sisteminin ilk yapıldığı 2007 yılında 492 bin 120 olan Yozgat'ın nüfusu her geçen yıl ortalama 15 bin azalarak 2015 yılı sonu itibariyle 419 bin 440 gerilemiştir. 2007 yılından bugüne kadar Yozgat merkez ilçenin nüfusuna yakın 72 bin 687 kişi memleketini terk etmiştir. Son on yıl içerisinde en çok göçü 13 bin 120 kişi ile 2015 yılında vermiştir (ADNKS, 2007-2015).

Ortadoğu'daki savaştan kaçıp Türkiye'ye sığınan milyonlarca mülteciden 5 bin 137'si Yozgat ilinde ikamet etmeye başlamıştır. Bu mültecilerden Suriyeli olanların sayısı da 2 bin 427 olarak açıklanmıştr. Suriyelilerin Türk ekonomisine etkilerine genel olarak bakıldı- 
ğında risk ve firsatların iç içe geçtiği bir tablo söz konusudur. Kiralarda artış gözlenmekte ve kiralık ev bulmak giderek zorlaşmaktadır. Özellikle küçük işletmelerde kaçak işçi çalıştırma yaygınlaşmakta, Suriyeli çalıştıran ve çalıştırmayan firmalar arasında haksız rekabet ortaya çıkmaktadır.

Nüfusuna oranlandığında oldukça yüksek oranda mültecinin ikamet etmesi ekonomik açıdan sıkıntllı olan Yozgat gibi iller açısından sorunun daha da büyümesine sebebiyet vermektedir. Sivas, Kayseri ve Yozgat illerini içine alan TR72 Bölgesi'nde 2014 yılında \% 9,6 olan işsizlik oranı 2015 yılında \% 9,7'ye çıkmıştır. 15 ve daha yukarı yaştaki nüfus 2014 yılında 1 milyon 734 bin kişi iken 2015 yılında bu rakam 27 bin kişi birden artarak 1 milyon 761 bin kişiye ulaşmıştr. Bölgede 2014 yılında 80 bin olan işsiz sayısı 2014 yılında 84 bine yükselmiştir. 2014 yılında \% 12,5 olan tarım dışı işsizlik oranı ise 2015 yılında \% 13,4 olmuştur (TÜik, 2014-2015). İşsizlik oranının bu şekilde yüksek olduğu ilde mültecilerin gelmesiyle bu sorun daha da büyümüştür. Yerel halk iş firsatlarının ellerinden alındığına inanmaktadır. Ücret düzeyinde önemli düşme gözlenmektedir.

\subsection{Sosyo-Kültürel Etkiler}

Sosyo-kültürel değişmelerin oluşmasında rol oynayan etkenler sayılamayacak kadar çok ve çeşitlidir. Bunlar içinden bazıları; nüfus hareketleri, coğrafi, biyolojik ve sosyal afetler, ekonomik gelişme ve sarsıntlar, teknolojik gelişme, şehirleşme, keşifler, icatlar, yeni lider ve ideolojilerin ortaya çıkması, rejim değişmeleri, misyoner faaliyetleri, diplomatik ilişkiler, öğrenci ve iş̧̧i mübadeleleri, kitle haberleşme vasıtaları, bilimsel kongreler ve çeşitli bilgi aktarma yolları, iç ve dış turizm hareketleri, iktisadi ve sosyal planlamalar vb. şeklinde sıralanabilir (Gürkan,1969: 470).

Türkiye'deki Suriyeliler konusu her şeyden önce bir sosyal uyum sorunudur. Mülteciler ile yerel halk arasında farklı dil, kültür ve yaşam tarzından kaynaklanan sorunlar yerel tepkinin en önemli nedenidir (ORSAM Rapor, 2015: 16).

\section{YÖNTEM}

Türkiye'deki Suriyelilerin \% 53,3'ü BM tarafindan çocuk sayılan 18 yaş altındaki kişilerden oluşmaktadır. Türkiye'deki Suriyeliler içinde özel koruma gerektiren çocuk ve kadınların oranı ise \% 75'in üzerindedir (HUGO, 2014: 13). Yozgat'ta yaşayan mültecilerin de büyük çoğunluğunu kadın ve çocuklar oluşturmaktadır.

Araştirma bölgesi olarak Yozgat'ın seçilmesinde göç veren bir il olarak Yozgat'a gelen mültecilerin yarattı̆ı nüfus artş̧ının önemi büyüktür. Gerek mültecilerin, gerekse de Yozgat halkının yaşadıkları değişim, uyum çabalarını da beraberinde getirmektedir kuşkusuz bu durum mültecilerde çok daha ileri düzeydedir.

Görüşmelerin gerçekleştirileceği hedef grup belirlenirken sağlıklı bir temsiliyet için gelir düzeyi, eğitim durumu, yaş grubu gibi kriterler göz önünde bulundurulmuştur. Yarı yapılandırılmış görüşme formunun taslağı oluşturulmuş, sahada uygulanabilirliğini anlamak amacıyla 2 kadın mülteci ile bir pilot çalışma gerçekleştirilmiştir. Geri bildirimler sonucunda bazı sorularda revizyona gidilmiştir. Bazı sorular eklenmiş veya çıkarılmışttr.

Sosyo-kültürel değişikliklere uyum durumları çok karmaşık ve katmanlı bir yapı arz etmektedir. Bunun en önemli nedeni görüşme gerçekleştirilen kadın mültecilerin kendi içlerinde etnik, dini aidiyetleri, köy ya da kent kökenli olmaları, yaşları, eğitim seviyeleri 
ve dolayısıyla yaşam tarzları gibi konularda homojen olmamalarıdır. Bu farklııklar değişime uyum deneyimlerini de etkilemekte ve çeşitlendirmektedir. Bu sebeple alıntlarda görüşmecilerin konuyla ilgili kendi ifadelerine yaşı, eğitim durumu ve mesleği eklenmiştir. Sosyo-kültürel yapının karmaşık ve katmanlı olması dolayısıyla katılımcı hakkında kapsamlı veri sağlamasa da yaş, eğitim durumu ve mesleki göstergelerle uyum deneyimlerinde farklılıkların etkisini göstermesi açısından önem taşımaktadır. Suriyeli kadın mültecilerin demografik, sosyal ve ekonomik durumlarını ortaya koymayı ve görüşmeler sonrası yapılan analizlerden edinilen veriler ışı̆̆ında olası sorunlara çözüm önerileri sunmayı hedefleyen bu çalışma amaç bakımından betimleyici saha araştırmasıdır.

Araştırmada insan eylemlerinin öznel anlamları içerdiğini bu nedenle insanla ilgili yapılacak araştırmalarda sayısal veriler kadar öznel algılamaların da önemli olduğunu ifade eden nitel araştırma yöntemi kullanılmıştır. Bu yöntem ile kadınların yaşadıkları durumu nasıl algıladıkları ve anlamlandırdıklarını kendi ifadeleri ile anlayabilmek amaçlanmıştır. Derinlemesine görüşmelere ek olarak veri toplama aşamasında gözlemlenen saha notları da araştırmaya dahil edilmiştir. Araştırmada bir ağdaki örnek olayla başlanıp, daha sonra o örnek olaydan aldığı bağlantılı ilişkilerle ilgili bilgilere dayanarak başka örnek olaylar belirlediği ve süreci tekrarladığı bir örnekleme türü olan kartopu örnekleme ile kadınlara ulaşılmıştr. Kartopu örneklemede önemli olan her bir kişinin ya da birimin bir diğeriyle doğrudan ya da dolaylı bir bağlantıyla bağlı olmasıdır (Neuman, 2008: 316).

Araşttrma verilerinin toplanmasında Ek II'deki görüşme formu kullanılmıştır. Görüşme soruları, görüşmelerden önce yapılan literatür çalışması sonucunda elde edilen bilgiler ve daha önce yapılmış bazı araştırmalardan yararlanılarak düzenlenmiştir. Soruların anlaşııı olmasına dikkat edilmiştir. Görüşme formu araştırmaya dahil edilen kadınlara bireysel olarak uygulanmıştı. Görüşmenin başlangıcında kadınları tanımaya yönelik (eğitim durumu, çalışıp çalışmadığı, eşinin ne iş yaptığı, gelir durumu v.b.) demografik sorular sorulmuştur. Derinlemesine görüşmede ise nasıl karşılandıkları, iletişim kurarken herhangi bir sıkıntı yaşayıp yaşamadıkları, sorun yaşadıkları alanların neler olduğu, Türk kültürünü sevip sevmedikleri, eğitim, sağılı hizmetlerinin yeterli olup olmadığı ve cinsiyetleri dolayısıyla daha büyük zorluk yaşadıkları herhangi bir durumla karşılaşıp karşılaşmadıkları başlıklarında görüşmeyi yönlendirici sorular sorulmuştur. Görüşmelerin süresi ve kalitesi görüşme koşulları, yanıt veren kişinin istekliliğine ve iletişim becerisine, görüşmenin yapıldığı yere vb. bağlı olarak farklılıklar göstermektedir. Görüşmelerin süresi 1-2 saat arasında değişmektedir. Görüşme kılavuzu aracılığıyla toplanan veriler yazılı metin haline getirilmiştir. Bu metinler ana başlıklar kapsamında değerlendirilerek araştırma bulgularında ayrıntılı olarak değerlendirilmiştir.

\section{ARAŞTIRMANIN BULGULARI}

Araştirma soruları "Yerleşim yeri olarak Yozgat, iletişim aracı olarak dil, kültürel farklıIıklar, temel hizmetlere erişim ve "kadın" olmaları dolayısıyla yaşadıkları olumsuzluklar konu başlıkları altında değerlendirilmiştir.

\subsection{Yerleşim Yeri Olarak Yozgat}

Katılımcıların Yozgat'ta ikamet etme süreleri farklılık göstermektedir. 4'ü sadece 3 aydır, 2'si 8 aydır, 1'i 1 yıldır, 3'ü 1.5 yıldır, 2'si 2.5 yıldır, 2'si 3 yıldır ve 1'i 4.5 yıldır Yozgat'ta yaşamaktadır. 
Tablo 1. Görüşme Gerçekleştirilen Mültecilerin Yozgat'ta İkamet Etme Süreleri

\begin{tabular}{ll} 
Kişi Sayısı & Yozgat'ta İkamet Süresi \\
4 & 3 ay \\
2 & 8 ay \\
1 & 1 yıl \\
3 & $1.5 \mathrm{yıl}$ \\
2 & $2.5 \mathrm{yıl}$ \\
2 & $3 \mathrm{yıl}$ \\
1 & $4.5 \mathrm{yıl}$ \\
\hline
\end{tabular}

Görüşme gerçekleştirilen katılımcıların tamamı Türkiye'de ilk olarak Ankara'ya geldiklerini oradaki Birleşmiş Milletler Mülteciler Yüksek Komiserliği (UNHCR) aracılığıyla da Yozgat'a gönderildiklerini ifade etmişlerdir.

"...Ailemle önce Ankara'ya geldik. Birleşmiş Milletler Mülteciler Yüksek Komiserliği (UNHCR)bizi Yozgat'a gönderdi." (34, Üniversite mezunu, SInıf öğretmeni).

Mültecilerin tamamı kendilerine doğrudan hangi ile gideceklerinin söylendiği bu konuda görüşlerinin sorulmadığını ifade etmişledir. Katılımcılara yöneltilen Yozgat halkı sizi nasıl karşıladı sorusuna büyük çoğunluğu "ılımlı, misafirperver" tanımlamalarıyla yanıtlarken, olumsuz deneyimleri olan katilımcılarla da karşılaşılmıştır. Yeni gelen mülteciler çok fazla olumsuzlukla karşılaşmadıklarını söylemişlerdir.

"...Yozgat halkı güzel karşıladı, bizlerle muhabbet kurup, sohbet ediyorlar." (22, Ortaokul mezunu, Ev kadını).

"Türk kültürünü çok sevdim. Yozgatlılar hem bizi çok iyi karşıladı hem de çok konuksever olduklarını bizlere gösterdiler." (19, Lise mezunu, Ev kadını).

"...Yabancı olduğumuz için selam vermeyen insanlar oluyor ya da vatanınızda durup savunarak ölseydiniz, neden kaçıyorsunuz ki diyenler oluyor ama tabi bu insanların tamamı çin geçerli değil çok iyi insanlar da var. Yemeğiniz yoksa deyip yemek veren komşularım da var." (36, Lise mezunu, Ev kadını).

“...Her geçen gün çoğalıyorsunuz bu kadar kalabalıksanız orada kalıp memleketinizi savunsaydınız da orda yaşasaydınız zaten iş, aş bulamıyorduk bir de siz geldiniz diyen insanlar oluyor." (39, Ortaokul mezunu, Kuaförde çalışıyor).

Görüşmelerde önemli bir nokta da kadınların büyük çoğunluğunun hiçbir zorluk yaşamamış olsalar bile "Yabancı olmanın, bir yerin yabancısı olma" nın başlı başına bir sıkınt olduğunu ifade etmeleridir.

"Her şey nasıl dört dörtlük olabilir ki, yabancı olmak bile başlı başına bir sıkıntiyken..." (29, Üniversite mezunu, Ingilizce öğretmeni).

"ilk geldiğimizde savaştan canımızı kurtardığımız için mutluyduk ama bir 
yandan bambaşka, yabancı bir yerde, tanıdıklarımız olmadan ne yapacağız, nasıl yaşayacă̆ız diye de çok endişeliydik. Çünkü her şeye yabancıydık, 2.5 yılda bile yeni yeni alıșmaya başladım ama zor." (34, Üniversite mezunu, Sınıf Öğretmeni).

Kadınlar günlük hayatta alışveriş, hastane vb. yerlerde yaşadıkları sorunlara da değinmişlerdir.

“... Alışveriş yaparken bazı satiıılar bizim yabancı olduğumuzu anlayıp daha pahalıa satmak istiyorlar ya da bazı kadınlar bizlerle sert konuşuyorlar ama tabi herkes böyle değil." (25, Ortaokul mezunu, Ev kadını).

Yozgat gibi göç veren bir ilde Suriyeli ve diğer yabancı uyruklu vatandaşların gelmesiyle ilin artan nüfus yoğunluğu ve demografik yapıdaki değişim yerleşik halkta kaygıyı da beraberinde getirmektedir. Bu durum araştırmamızın dikkat çekici bulgularından biri olması bakımından önem taşımaktadır.

\section{2. İletişim Aracı Olarak Dil}

Göç edenler farklı bir dil öğrenmede, yabancı bir kültüre uyum sağlamada alışkanlıklarından farklı değişik bir yaşama alışmada güçlüklerle karşılaşabilmektedirler (Gün, 2011:272). Sosyo-kültürel yapının önemli boyutlarından birisi olarak "dil" araştırmamızda doğrudan iletişim aracı olarak değerlendirmeye alınmıştr. Suriyeli mültecilerin ana dillerinin Arapça olması nedeniyle Türkçe ifade ve konuşmalarda sorun yaşamaları olasılı̆̆ı oldukça yüksektir. Görüşmelerde de kadınların gündelik hayatta karşııındakileri anlayamama ya da kendini ifade edememe yani iletişim ortamının oluşturulamamasının en büyük sıkıntıları olduğu farklı şekillerde ifade edilmiştir.

"Türkşe öğrenmeye başladıkça daha az sıkınt çekiyorum. Hastanede de iletişim kurmakta çok zorlanıyoruz, kendi içimizden Türkşeyi daha iyi bilenlerle gitmeye çalışıoruz." (26, Üniversite mezunu, Ingilizce öğretmeni).

"...Dil bilmediğimiz için çok zorlanıyoruz, bu yüzden öğrenmeye çalışıyoruz." (45, Ilkokul mezunu, Ev kadını).

"Dil sıkıntısını çok yaşıyoruz içimizde daha iyi bilenler tercümanlık yapıyor bizlerde öğrenene kadar bu şekilde devam etmeye çalışıoruz." (55, ilkokul mezunu, Ev kadını).

"Televizyon, radyo, sinemayı dil sıkıntisı nedeniyle anlayamıyorum" (19, Lise mezunu, Ev kadını).

Görüşülen Suriyeli kadınlardan sadece 3'ü Türkçe öğrenmek için halk eğitim kurslarına katlarak profesyonel destek almaktadır. Türkçe öğrenmeyi hem gündelik hayatta iletişim kurabilmek hem de iş bulup çalışabilmek amacıyla istemektedirler. Halk eğitim kurslarına katılmayan kadınların büyük çoğunluğu bu kurslara katılmayı çok daha büyük sorunları olduğunu düşündükleri için vakit kaybı olarak görmekte, diğerleri ise eşlerinin izin vermediği gerekçesiyle dil sıkıntılarını daha kısa sürede çözebilecekleri bu tarz olanakları kullanmamaktadır.

"Ilk zamanlar dil sıkıntisı nedeniyle pazarlardan alışveriş bile yapamıorduk, anlaşamıyorduk. O yüzden önce yiyecek, içecek gibi gündelik ihti- 
yaçlarımızı anlatacak kelimeleri öğrendik, şimdi cümle bile kurabiliyoruz. Yaşım 51 ama hani yeni konuşmayı öğrenmeye çalışıllar ya çocuklar onlar gibi olduk..." (51, ilkokul mezunu, Ev kadını).

"Günlük hayatta iletişim kurmakta zorlanıyordum ama halk eğitimde Türkçe kursuna katlıp öğrenmeye başladıktan sonra daha az zorlanıyorum." (34, Üniversite mezunu, SInı öğretmeni).

"Giyim-tekstil, lokanta, kuaför gibi işlerde çalışmak istiyorum ama o işler için bile bizi tercih etmiyorlar. İ̧ aradığım yerlerde yabancısın, Türkçe bilmiyorsun deniliyor." (22, Ortaokul mezunu, Ev kadını).

\subsection{Kültürel Farklılıklar}

Bireyler içinde yaşadıkları topluluğun gelenek ve göreneklerinden, tutum ve beklentilerinden etkilenmekte ve dolayısıyla da farklı davranış, düşünce ve tutumlar geliştirmektedirler. Bu yüzdendir ki, bireyin içinde doğup büyüdüğü kültür önemli bir yere sahiptir. İnsanoğlu kültür sayesinde içinde yaşadı̆̆ı çevreye uyum sağlamaktadır. Her toplumun kültürü kendine özgü bir takım niteliklerden oluşmaktadır. Sahip olunan norm ve değerler bütünü herhangi bir kültürde aynı ya da benzer bir biçimde olmayabilir. Kültür ile ilgili değişkenler incelendiğinde, töre, aile, soy, sanat, eğitim, yerleşim şekilleri, üretim ve tüketim ilişkileri, yönetim, beslenme, sağlık, inanç sistemleri, kişilik sistemleri ve dil gibi kavramların ön plana çıktğı̆ görülmektedir (Güvenç, 1994).

Görüşme gerçekleştirilen kathımcıların tamamına yakınının "ilk zamanlar çok sıkınt yaşadım. Ama şimdi biraz daha alışım." ifadesiyle sözlerine başladığı gözlemlenmiştir. Kathlımcılar sosyo-kültürel ve ekonomik değişikliklere uyum sağlamak için zamana ihtiyaç duyduklarını ifade etmişlerdir.

"Türk kültürünü çok sevdim. Bizim oralarda erkeklerle kadınlar konuşamıyor ama burası bu konuda daha rahat. Çarşıya, pazara gitmek daha kolay. Güvenlik sıkıntısı yok, savaş yok. Özellikle güvenlik sıkıntısı nedeniyle vatanımıza geri dönmek istemiyoruz. Çocuklar bile çalınıyor. Burada daha güvenliyiz." (45, Ilkokul mezunu, Ev kadııı).

"Bize iyi davranıyorlar, Türklerde misafir sevme varmıs (misafirperverlik), komşularımız bize karnınız aç mı? tok mu? diye de soruyor. Misafir sevme adetmiss, güzel yani o yüzden bir sıkınt yaşamıyoruz." (42, ilkokul mezunu, Ev kadını).

"...Türk kültürünü çok sevdim ama bazı adetler zor geliyor. Mesela el öpmek, bizim kültürümüzde böyle bir şey yok." (36, Lise mezunu, Ev kadını).

Görüşmelerde katılımcılar ülkelerinde yaşadıkları kısıllamaları burada yaşamadıklarını, çok daha rahat olduklarını belirtmişlerdir. Kathlımcıların ifadelerinden sosyo-kültürel değil ama sosyo-ekonomik açıdan zorluk yaşadıkları anlaşılmaktadır.

\subsection{Temel Hizmetlere Erişim}

Temel hizmetler alanında Suriyeliler çoğunlukla barınma, sağlık ve eğitim alanında sorunlarla karşılaşmaktadır (Ataman, 2015: 29). Eğitim ve sağlık gibi temel hizmetlerin yeterli bulunup bulunmadığına ilişkin araştırma sorumuza katıımcıların tamamına yakını 
bu hizmetlere erişimde herhangi bir sıkınt yaşamadıklarını ama dil sorunu nedeniyle zorlandıklarını ifade etmişlerdir.

"Annem babam hastalandığında tedavi ettirdim. Sağlık, eğitim konularında bir sıkınt yaşamıyoruz." (19, Lise mezunu, Ev kadını).

"Sağlık ve eğitim hizmetlerinin yeterli olduğunu düşünüyorum." (36, Lise mezunu, Ev kadını).

Mültecilere göçmen ofislerinde kayıt yaptırmaları halinde sağlık hizmetleri ve ilaçlara ücretsiz erişim hakkı tanınmaktadır. Kayıtlı mülteciler Türkiye Cumhuriyeti vatandaşları ile aynı sağlık hizmetlerine sınırsız erişebilmektedir. Katılımcılar hastane personelinin hizmet sunma, Yozgat halkının da hizmet paylaşımı konusunda sıkınt yaratmadıklarını ifade etmişlerdir. Çeşitli sebeplerle kayıt yaptırmayanlarına ise hiçbir hak sağlanmamaktadır. Katlımallar arasında da çeşitli sebeplerle kayıt yaptıramadığı ve kaydı olmadığı için sağlık hizmetlerine erişimde sıkıntı yaşayanlar olmuştur.

"Hastaneye gidebiliyoruz ancak paramız olmadığı için ilaçları alamıyoruz." (55, Illkokul mezunu, Ev kadını).

Sağlık alanlarında gerçekleştirilen iyileştirme çalışmalarından ve kendi ülkelerinde yarım kalan eğitimlerine devam edebilme imkanının sağlanmasından Suriyeli mültecilerin memnun oldukları görülmüştür.

“...Burada açıöğretim 8. Sınıfta okumaya devam ediyorum." (45, ilkokul mezunu, Ev kadını).

"...Lise mezunuyum, üniversiteye giderek okumak isterdim ama maddi sıkıntılardan dolayı yapamayacağım için burada açıöğretimden okumayı düşünüyorum. Böyle bir firsatın olması çok güzel." (27, Lise mezunu, Markette çalışıor).

"Eğitim konusunda sıkıntılar var. Özellikle küçük çocuklar için kreş ya da yarım gün bakım yerlerinin sayısı çok az. Sağılk hizmetleri konusunda da önceleri doktor sayısı az, hasta çok olduğu için uzun sıralar oluyordu. Şimdi şehir hastanesi kurulduktan sonra iyileşmeye başladı."(32, Üniversite mezunu, Avukat).

\section{5. "Kadın” OImaları Dolayısıyla Yaşadıkları Olumsuzluklar}

Biyolojik olarak "kadın" ve "erkek" olmak, doğal ve doğuştan olarak adlandırılırken, "kadınlık" ve "erkeklik" ise toplumsallaşma süreci ile beraber kültürel bir yapılanmadır (Hepşen, 2015: 158). Biyolojik cinsiyetin toplumsal cinsiyete dönüşmesinde dönüm noktası, toplumsal yaşamın ortak alan ve mahrem alan biçiminde ayrılması ve mahrem alanın kadın merkezli olarak tanımlanmasıdır. Bu dönüşüm sonucunda kadının yaşamı hane içi ile sınırlanmakla kalmamış, kadın sınırları tanımlanmamış olan "aile namusu" nu korumakla da yükümlü kılınmıştır (Erol, 2008:215).

Toplumsal cinsiyet eşitsizliği farklı boyutlardaki iktidar ilişkilerinin sonucu olarak toplumun kadın ve erkeğe ilişkin algısından kaynağını almaktadır (Akın ve Demirel, 2003: 77). Toplumsal cinsiyet eşitsizliği nedeniyle kadınlar daha az sağlıklı, daha düşük eğitimli, daha az işgücüne katılan, daha az gelir getiren işlerde çalışan pozisyondadır. Dünya 
nüfusunun yarısını oluşturan kadınların ikinci sınıf insan muamelesi görmeleri, düşük olan toplumsal statüleri, kaçınılmaz olarak onların verilen sağlık ve eğitim gibi hizmetleri kullanmalarını, hizmetlerden zamanında yararlanmalarını da olumsuz etkilemektedir (Bal, 2014: 15). Bireyin cinsiyeti nedeniyle firsatlardan, kaynaklardan ve hizmetlerden herhangi bir ayrımcılık olmaksızın eşit olarak yararlanabilmesi gerekmektedir ancak mevcut durumun bunun aksi olması cinsiyet eşitsizliğinin sürdürülmesine ve kadınların toplumda ikincilleştirilmesine sebebiyet vermektedir.

Elverişsiz konaklama mekanları, toplu yaşamak zorunluluğu, gelir düzeyi yetersizliği, sağlık sigortalarının olmaması, dil engeli vb. nedenlerle göç, mültecileri farklı boyutlarda etkilemektedir. Bu olumsuz etki, toplumsal statüleri ve geleneksel yaşam kalıpları nedeniyle erkeklere kıyasla kadınları daha fazla etkilemekte ve dezavantajlı hale getirmektedir. Ülkelerinde yaşadıkları zulümden kaçan mülteci kadınlar, bu ve benzeri nedenlerle çocuklar gibi özel korumaya intiyaç duyulan "hassas grup" kapsamında ele alınmaktadır (Akt. Gümüş, Kaya vd., 2017: 3-4).

Türkiye'de kayıt dışı ekonomi çok yaygın olduğundan bu enformel alanda ucuz işgücü olarak çocuk ve kadın emeğinin yaygınlaştığı görülmektedir. Görüşülen katılımcılar özellikle çalışma hayatında yaşadıkları olumsuzluklar üzerinde durmuşlardır. Kadınlar kendi ülkelerinde sadece belli başlı birkaç meslek sahibiyse çalışabildiklerini, bunların dışındaki işlerde çalışılamadığını ifade etmiştir. Tabi bu meslekler için eğitim alınması sürecinde de ailenin kız çocuğunun okutulması gerektiğine inancının tam olması gerektiği, dışarıdan insanların olumsuz söylemlerine aldırış etmemesi ve kız çocuğunun eğitimini destekleyerek kesintiye uğramasına engel olması için bunun büyük önem taşıdığı belirtilmiştir.

"...Kadınlar ancak avukat, öğretmen, doktor vb. meslek sahibi olduğunda kendi mesleklerini yapabiliyorlardı diğer alanlarda çalışmaları çok da uygun görülmezdi. Bu yüzden savaş ortamı sona erse bile geri dönmeyi düşünmüyorum. Buradan da Amerika ya da Kanada'ya geçmek istiyoruz." (36, Lise mezunu, Ev kadını).

Eğitim ve gelir seviyesinin düşüklüğü, olumsuz yaşam koşulları özellikle kadınları her tür istismara açık hale getirmektedir. Kadınlar eğitim seviyelerinin düşük olması sebebiyle vasıfsız işlerde çalışmak zorunda kalmaktadır. Emek yoğun, ekonomik dalgalanmalardan daha çabuk etkilenen, güvencesiz, düşük ücret ödenen işlerde çalışan kadınlar taciz ve istismara açık hale gelmenin yanı sıra gerekçesiz bir şekilde işlerinden de olabilmektedir.

"Kadın olduğum için sıkıntı yaşadım. Balık halinde çalıştı̆ımda orada çok erkek vardı, sözlü taciz ettiklerinde rahatsı olduğumu söyledim ve onlarda bir daha gelme dediler işimden oldum." (25, Ortaokul mezunu, Ev kadını).

Görüşmelerde kadınların taciz, istismar korkusu, toplumsal baskı, daha iyi hayat koşullarına erişimi isteme vb. gibi ekonomik gerekçelerle genç kızların "evliliği kurtuluş olarak görme" durumunun yaşandığı, evli kadınlar açısından da "evli olma"nın kendilerini olumsuzluklardan koruduğu düşüncesinde oldukları gözlemlenmiştir.

"Evliyim 2 çocuğum var. Kendimizden önce düşünmemiz gereken çocuklarımız olduğu için hayatımız daha zor. Evli olduğum için bekar genç kızlara nazaran daha az sorunla karşılaşıyorum." (34, Üniversite mezunu, Sınıf ögretmeni). 


\section{SONUÇ}

Kısa süreli ve geçici bir durum olarak görülen göç, gün geçtikçe kalıcı bir hal almaktadır. Bu durum göç eden ve göçü kabul eden insanların psikolojilerini ve tepkilerini etkilemektedir. Suriyeliler ya Türkiye'de uzun süre kalacak ya da önemli bir kısmı yaşamlarını Türkiye'de sürdürecektir. Türkiye, devam eden mülteci akınını dikkate alarak entegrasyon politikalarına öncelik vermelidir (İçduygu, 2015: 2). Suriyeli mülteciler arttk Türkiye'nin bir gerçeği ise, bunun olumsuz etkilerini azaltacak, olumlu etkilerini daha fazla hayata geçirecek önlemler üzerinde durulmalıdır.

Araştırma bölgesi olan Yozgat ilinde İçişleri Bakanlığı'nın 2014 yılı verilerine göre; 50 Suriyeli mülteci yaşamakta iken Mart 2017 itibariyle kayıtlı olanların sayısının 3 bin 352'ye yükselmesi ve bu sayının nüfusu 421.041 olan Yozgat'ın kendi nüfusu ile karşılaştııldığında \%0.80 sonucunu ortaya çıkarması oldukça önemlidir. Ekonomik ve sosyal sebeplerle göç veren bir il olan Yozgat'a yönelen bu göç dalgası işsizlik, geçim sıkıntısı vb. toplumsal sorunları da beraberinde getirmektedir. Görüşmelerdeki ifadeler Suriyelilerin ülkelerine yakın veya uzak gelecekte geri dönmeyecekleri ve Türkiye'de yaşamlarını sürdürmeyi tercih edeceklerini göstermektedir.

Görüşmelerde katılımcılar hayatlarının geri kalan kısmını Türkiye'de geçirmek istediklerini ifade etseler de sadece 3 katılımcı dışında neredeyse tamamına yakınının ne kendisi ne de birlikte göç ettiği aile bireyleri ya da yakınları düzenli gelir getirebilecek bir işte çalışmamaktadır. Dil, eğitim ve ülke genelinde de yaşanılan işsizlik sebebiyle istihdam sıkıntısı yaşamakta bu sebeple de hayatını ne şekilde idame ettireceğini bilememekte, gelecek kaygısı yaşamaktadır. Büyük çoğunluğu daimi iş arayışında olan katılımcılar bulabilirlerse ya günü birlik işlerde cüzi miktarda ücret kazanarak, ya da komşu, eş, dost desteğiyle ki bunun sürekliliğinin olmayacağının bilincindeler... geçimlerini sağlamaya çalışmaktadır. İstihdam konusu mevcut durumda sorun olarak karşımızda durmaktadır ancak bu sorunun çözüme kavuşturulması durumunda toplumsal uyumu kolaylaştracağı görülmektedir.

Görüşmelerde katılımcıların ifadelerinden dikkat çekici olan ve üzerinde durulması gereken bir nokta da Türkçe dil eğitiminin planlı ve düzenli bir şekilde yapılmasının, bu konuya önem ve öncelik verilmesinin Suriyelilerin sosyal uyumunu hızlandıracak ve kolaylaştıracak bir etki yaratacağını göstermesidir. Katılımcıların tamamı dil bilmemeleri dolayısıyla yaşadıkları sıkıntıların diğer tüm sorunlarının (günlük ihtiyaç, eğitim, çalışma vb.) sebebi olduğunu farklı şekillerde ifade etmiştir.

Türkiye'de Suriyeliler konusunda zaman zaman ırkçılığa, yabancı düşmanlığına, nefrete varacak olumsuz tavırlara rağmen genelde "toplumsal kabul" düzeyinin olağanüstü yüksek olduğunu ortaya koymaktadır (Erdoğan, 2014: 5). Araştırmamızda da katılımcıların yarısından daha azı "ırkçılığa, yabancı düşmanlığı" na maruz kaldığından bahsetmiş ise de bu kişiler toplumun tamamının bu şekilde olmadığını, bazılarının da bugün yiyecek yemeğiniz var mı ? yok mu? diye sorup, yardımcı olduklarını ifade etmiştir.

Ataerki, erkeklerin kadınların emekleri ve bedeni üzerinde tahakküm kurduğu eşitsiz cinsiyet ilişkileri sistemini ifade etmektedir. Araştrrma örneklemimizi oluşturan Suriyeli mülteci kadınlar ülkelerinden göç ederken ve yerleştikleri Yozgat'ta "kadın olma"ları özelinde yaşadıkları sorunları ifade etmişlerdir. Görüşmelerde de kadınların biyolojik, doğal ve doğuştan "kadın" olmak dışında toplumsallaşma süreci ile beraber kültürel 
bir yapılanmayı içeren "kadınlık" dolayısıyla toplumsal cinsiyet eşitsizliğinin yansımaları olarak görebileceğimiz durumları sorunlar olarak ifade ettikleri görülmüştür. Kadınların yaşadıkları sıkıntllarda eğitim hakkı, üretime katılma yani çalışma hakkı, ihmal ve istismardan korunma haklarının ihlal edilmesi sebebiyle statülerinin düşürüldüğü ve daha yoğun cinsiyet ayrımcılı̆̆ına maruz kalmalarına neden olunduğu görülmektedir. Ataerkil ve geleneksel toplumlarda geleneksel cinsiyet kalıp yargılarının geçerliliğini koruması toplumsal cinsiyet eşitsizliğinin kuşaklar boyunca devam etmesine ne yazık ki meşru bir zemin sağlamaktadır.

Türkiye'deki Suriyelilere ilişkin olarak yapılan saha araştırmalarında bölgede Suriyelilere yönelik olumsuz tepkinin en önemli nedenlerinin başında Suriyeliler ile yerel halk arasında farklı dil, kültür ve yaşam tarzından kaynaklanan sorunların geldiği görülmekte bu durumda uyum sürecinin zayıf yönlerini oluşturmaktadır (Oytun ve Gündoğar, 2015: 16). Görüşmeleri gerçekleştirebilmek için Suriyelilerin yaşadıkları mahallelere gidildiğinde işsizlik ve maddi sıkıntıların da etkisiyle merkezden uzak ve birbirlerine yakın olabilecekleri şekilde yaşadıkları görülmüş bu durumun da uyum sürecini olumsuz etkilediği gözlemlenmiştir.

Görüşmelerde yaşları daha genç olan katılımcıların Türk toplumunu misafirperver, hoşgörülü olarak tanımladıkları, daha ileri yaşta olanların ise yerli halkın kendilerine karşı olumsuz tavır takındığı yönünde düşüncelerinin olduğu görülmüştür. Dil eğitiminde de gençler yaşı ileri olanlara göre çok daha hızlı öğrenerek ilerleme kaydetmektedir. Toplumlar arası kültürel farklııılara genç katılımcıların yaşı ileri olan katılımcılara göre daha hızlı adapte olabildiği görülmektedir. Eğitim düzeylerine göre üniversite mezunu meslek sahibi katlımcıların mesleklerini Türkiye'de de yapmak istemelerinden dolayı Türkçeyi gündelik hayatlarının yanı sıra mesleklerinde çalışırken kullanmak için öğrenmek istedikleri, daha düşük eğitim seviyesine sahip olan kadınların ise gündelik hayatlarını sürdürebilecek, kendilerini ifade edebilecek kadar öğrenmek istedikleri görülmektedir. Üniversite mezunu kadınlar ayrıca Türk eğitim sisteminde sıkıntılar olduğunu özellikle kreş, anaokulu gibi okul öncesi eğitim kademelerinde düzenlemelere ihtiyaç olduğunu ifade etmiştir.

Dil, kültür ve yaşam tarzından kaynaklanan nedenlerle Suriyeliler bazı sosyal faaliyetlerden faydalanamamaktadır. Özellikle Suriyeli kadın, genç ve çocukların sosyal faaliyetlere yönlendirilmesi sıralanan birçok toplumsal etkiyi sınırlandırabilir. Uyum süreci devam ettiği dönemde Suriyelilerin faydalanabileceği sosyal alanların inşası ve hizmetlerin verilmesi faydalı olabilir (ORSAM, 2015: 39). Göç dolayısıyla mülteciler kendi sosyo-kültürel özelliklerinden uzaklaşsalar da Türk toplumu açısından yeni sosyo-kültürel özelliklerin kazanılması önem taşımaktadır. 


\section{EK-1. KATILIMCILAR}

\begin{tabular}{|c|c|c|c|}
\hline Yaş & Eğitim & Suriye'de Meslek & Türkiye'de Meslek \\
\hline 29 & Üniversite mezunu & İngilizce Öğretmeni & İşsiz / İş arıyor \\
\hline 36 & Lise mezunu & Ev kadını & İşsiz / İş arıyor \\
\hline 45 & İlkokul mezunu & Ev kadını & İşsiz / İş arıyor \\
\hline 34 & Üniversite mezunu & Sınıf Öğretmeni & İşsiz / İş arıyor \\
\hline 19 & Lise mezunu & Ev kadını & İşsiz / İş arıyor \\
\hline 26 & Üniversite mezunu & İngilizce Öğretmeni & İşsiz / İş arıyor \\
\hline 32 & Üniversite mezunu & Avukat & İşsiz / İş arıyor \\
\hline 25 & Ortaokul mezunu & Ev kadını & İşsiz / İş arıyor \\
\hline 22 & Ortaokul mezunu & Ev kadını & İşsiz / İş arıyor \\
\hline 55 & İlkokul mezunu & Ev kadını & İşsiz / İş arıyor \\
\hline 34 & Üniversite mezunu & Sınıf Öğretmeni & İşsiz / İş arıyor \\
\hline 42 & İlkokul mezunu & Ev kadını & İşsiz / İş arıyor \\
\hline 51 & İlkokul mezunu & Ev kadını & İşsiz / İş arıyor \\
\hline 39 & Ortaokul mezunu & Ev kadını & Kuaförde çalışıyor \\
\hline 27 & Lise mezunu & Ev kadını & Markette çalışıyor \\
\hline
\end{tabular}

\section{EK-2. NITEL GÖRÜŞME FORMU}

- Kaç yıldır Yozgat'ta yaşıyorsunuz? Yozgat'ı yerleşim yeri olarak seçme nedeniniz nedir?

- Günlük hayatta Türklerle iletişim kurarken zorlanıyor musunuz? Zorlanıyorsanız özellikle hangi konularda sıkınt yaşıyorsunuz?

- $\quad$ Sizce Yozgat halkı sizi nasıl karşıladı? Karşılaştığınız olumlu ve olumsuz durumlara örnek verebilir misiniz? Dışlanılmış hissettiniz mi?

- Türk kültürünü sevdiniz mi? Kültür çatışması veya sosyo-kültürel bütünleşme yaşıyor musunuz?

- Yozgat ilindeki kültürel faaliyetleri yeterli buluyor musunuz?

- $\quad$ Sizce eğitim ve sağlık hizmetleri yeterli mi?

- Cinsiyetiniz dolayısıyla "kadın olma" nız nedeniyle çok daha büyük zorluklarla karşılaştğınızı düşünüyor musunuz? 


\section{KAYNAKÇA}

Akın A. ve Demirel S. (2003). Toplumsal Cinsiyet Kavramı ve Sağlığa Etkileri. C. Ü. Tıp Fakültesi Dergisi, 25:7382.

Akkayan, T. (1979). Göç ve Değişme. İstanbul: İstanbul Üniversitesi Edebiyat Fakültesi Yayınları No:2573.

Arslanoğlu, i. (1996). Sosyo-Kültürel Bütünleşme ve Türkiye'de Bölücülük. Yeni Forum Dergisi, 17(328):39-44.

Ataman, H. (2015). Mülteci mi, Sığınmacı mı, Misafir mi?, Görüş Dergisi, 88, İstanbul.

Bal, D. M. (2014). Toplumsal Cinsiyet Eşitsizliğine Genel Bakış. Kadın Sağlığı Hemşireliği Dergisi (KASHED), 1(1), 15-28.

Biehl, K. (2008). Migration "Securitization" and İts Everyday İmplications: An Examination of Turkish Asylum Policy and Practice-Best Participant Essays Series 2009/1.

Buz, S. (2008). Türkiye Sığınma Sisteminin Sosyal Boyutu. TBB Dergisi, (76), 120-130.

Çakır, S. (2011). Türkiye'de Göç, Kentleşme/Gecekondu Sorunu ve Üretilen Politikalar. SDÜ Fen Edebiyat Fakültesi Sosyal Bilimler Dergisi, 23, 209-222.

Demir, E. T. (2008). Göç ve Sosyo-Kültürel Değişim. Ankara Üniversitesi Sosyal Bilimler Enstitüsü, Antropoloji (Sosyal Antropoloji) Anabilim Dalı, Yüksek Lisans Tezi, Ankara.

Dikeçligil, B. (1997). Bir Analiz Modeli Denemesi: Sosyal Yapı ve Toplumsal Yapı. Yeni Türkiye Dergisi.

Dinçer, B. O. Federici, V. (vd.) (2013). Suriyeli Mülteciler Krizi ve Türkiye: Sonu Gelmeyen Misafirlik. Brookings Enstitüsü ve Uluslararası Stratejik Araştırmalar Kurumu (USAK). Ankara: Karınca Yayınları.

Erdoğan, M.M.,(2014). Türkiye'deki Suriyeliler: Toplumsal Kabul ve Uyum Araştrrması. Ankara: Hacettepe Üniversitesi Göç ve Siyaset Araştırmaları Merkezi.

Erol M. (2008). Toplumsal Cinsiyetin Tutumlar Üzerindeki Etkisi. C.Ü. Sosyal Bilimler Dergisi, 32:199-219.

Gümüş, G., Kaya, A.vd. (2017). Suriyeli Mülteci Kadınların Üreme Sağlı̆̆ı Sorunları. Kadın Sağlığı Hemşireliği Dergisi, 3(1), 1-17.

Gürkan, Ü. (1969). Sosyal Değişmeler. Ankara: Ankara Üniversitesi Siyasal Bilgiler Fakültesi Yay. No: 280, Sevinç Matbaası.

Güvenç, B. (1994). İnsan ve Kültür (Altıncı baskı). İstanbul: Remzi Kitabevi.

Hacettepe Üniversitesi Göç ve Siyaset Araştrrmaları Merkezi (HUGO) (2014). Türkiye'deki Suriyeliler: Toplumsal Kabul ve Uyum Araştırması. Ankara: HUGO Yayınları.

Hepşen, Ö. (2015). Tevrat, İncil ve Kuran-ı Kerimde Kadın Bedeni. Ankara Üniversitesi Sosyal Bilimler Enstitüsü, Yüksek Lisans Tezi, Ankara.

İçduygu, A. (2015). Syrian Refugees in Turkey The Long Road Ahead. Transatlantic Council on Migration: A Project of the Migration Policy Institute.

İnsan Hakları ve Mazlumlar İçin Dayanışma Derneği (MAZLUMDER) (2014). Kamp Dışında Yaşayan Suriyeli Kadın Mülteciler Raporu.

Kibaroğlu, M. (2011). Arap Baharı ve Türkiye. Adam Akademi, 2, 26-36.

Mozaik Kadın ve Aile Derneği (2015). Gaziantep’teki Mülteci Kadınlar ve Ailelerine Yönelik Uyum Araştırma Raporu.

Neuman, W. L. (2008). Toplumsal Araştırma Yöntemleri: Nitel ve Nicel Yaklaşımlar. (Çev: S.,Özge). İstanbul: Yayın odası.

Oğuzlu, T. (2011). Arap Baharı ve Yansımaları. Ortadoğu Analiz Dergisi, cilt:3, sayı:36.

Oytun, O. ve Gündoğar, S. S. (2015). Suriyeli Sığınmacıların Türkiye'ye Etkileri Raporu, ORSAM- TESEV Rapor No: 195, Ankara.

Ortadoğu Stratejik Araşttrmalar Merkezi (ORSAM) (2015). Suriyeli Mültecilerin Türkiye'ye Etkileri. Rapor No:195.

Tutar, H. (2016). Sosyal Psikoloji: Kavramlar ve Kuramlar. İstanbul: Seçkin Yayıncılık.

TÜiK, 2014-2015 Nüfus İstatistikleri.

INTERNET KAYNAKLARI

Gün, Z. (2011). Iltica, Uluslararası Göç ve Vatansızlık: Kuram, Gözlem ve Politika. http:// www.unhcr.org.tr/ uploads/root/v._b\%C3\%B6l\%C3\%BCm.pdf.

Yozgat Valiliği III Göç İdaresi Müdürlüğü: http://yozgat.goc.gov.tr/tr/page/goc_gecici-koruma-4713.

http://www.unhcr.org/turkey/home.php?content=28\&page=29.

http://bianet.org/bianet/bianet/167434-multeci-gocmen-siginmaci-arasinda.ki-farklar. 